\title{
Efisiensi Penyisihan Logam Fe dengan menggunakan Instalasi Pengolahan Lindi Compact (IPLC)
}

\author{
SEPTI AGRIANI', RACHMAWATI S DJ ${ }^{1}$
}

1. Jurusan Teknik Lingkungan, Fakultas Teknik Sipil dan Perencanaan, Itenas,Bandung

Email :septiagriani@yahoo.com

\begin{abstract}
ABSTRAK
Lindi berasal dari proses dekomposisi sampah yang mengandung materi tersuspensi, terlarut, dan terekstraksi, sehingga kandungan lindi sangat berbahaya.Pada penelitian ini akan diteliti logam Feyang terdapat dalam lindi TPA Sarimuktiserta parameter pendukung, seperti pH, suhu, DO, kekeruhan dan TSS. Pengolahan dilakukan dengan menggunakan reaktor Instalasi Pengolahan Lindi Compact (IPLC) secara semi kontinu dengan kombinasi antara anaerob dan aerob. Waktu detensi yang digunakan, yaitu 31,33 jam yang didapatkan dari tracer test. Proses seeding dan aklimatisasi dilakukan menggunakan bakteri fakultatif, dengan dua media lekat, yaitu kaldness dan bioball. Berdasarkan dari karakteristik awal didapatkan beberapa parameter yang tidak memenuhi baku mutu Peraturan Menteri Lingkungan Hidup Tahun 2016 Tentang Baku Mutu Lindi Bagi Usaha dan/atau Kegiatan Tempat Pemrosesan Akhir Sampah, yaitu BOD 5 sebesar 1.071,55-1.593,29 mg/l, COD sebesar 4.800-6.400 mg/l dan TSS sebesar 470-556 mg/l. Berdasarkan hasil penelitian, IPLC mampu menyisihkan Fe sebesar 53,87\% dari konsentrasi awal.
\end{abstract}

Kata kunci: Air Lindi, Logam Berat, IPL Compact, Sarimukti

\begin{abstract}
Leachate originates from waste decomposition process which contains suspended, dissolved, and extracted material, so that leachate content is considered as hazardous. In this research, leachate was obtained from municipal solid waste (TPA) Sarimukti. Parameters to be studied is heavy metals Fe which contained in the leachate from TPA Sarimukti. In addition several supporting parameters, such as $\mathrm{pH}$, temperature, DO, turbidity and TSS are studied. The treatment was carried out using a pilot plant scale reactor of Leachate Compact Processing Plant (IPLC), operated semi-continuously using biological, physical and chemical processing systems as well as anaerobic-aerobic configurations. The detention time used were 31,33 hours which was obtained from the tracer test. The seeding and acclimatization process was carried out using facultative bacteria, with two sticky media, caldness and bioball. Based on the results, IPLC was able to eliminate Fe by 53,87\% from the initial concentration.
\end{abstract}

Keywords: Leachate, Heavy Metal, IPL Compact, Sarimukti 


\section{PENDAhuluan}

Tempat Pembuangan Akhir (TPA) Sarimukti merupakan TPA yang menampung sampah dari tiga wilayah,yakni Kota Bandung, Kota Cimahi, dan Kabupaten Bandung Barat. Jenis sampah yang dibuang ke TPA Sarimukti merupakan campuran dari sampah rumah tangga, pasar, industri dan rumah sakit (Pratama, Y., dan Soleh, A, Z. 2010). Timbulan sampah di TPA akan terbasuh oleh air hujan dan menimbulkan lindi.

Lindi mengandung materi tersuspensi, terlarut, dan terekstraksi dari sampah, sehingga kandungan lindi tersebut sangat berbahaya (Tchobanoglous et al, 1993). Karakteristik lindi sangat tergantung dari komposisi sampah yang tertimbun di dalam landfill di TPA. Air lindi pada umumnya mengandung senyawa-senyawa organik (hidrokarbon, asam humat, fulfat, tanat dan galat) dan anorganik (natrium, kalium, kalsium, magnesium, klor, sulfat, fosfat, fenol, nitrogen dan senyawa logam berat) yang tinggi (Parsons,2002). Menurut Damanhuri, E (2008), logam yang terdapat dalam lindi, yaitu logam terlarut, seperti senyawa sulfat dari $\mathrm{Ca}, \mathrm{Mg}$; senyawa bikarbonat dari Fe, Ca, Mg; senyawa oksida dari Sn, Zn, Cu.Logam berat pada lindi berasal dari limbah bahan, berbahaya dan beracun (B3), seperti kabel listrik, batu baterai, besi, cat pelapis anti karat, dsb.

Menurut Darmono (1995), adanya logam berat diperairan sangat berbahaya, baik secara langsung terhadap kehidupan biota perairan, maupun efeknya secara tidak langsung terhadap kesehatan manusia. Hal ini berkaitan dengan sifat-sifat logam berat yang sulit didegradasi, sehingga mudah terakumulasi dalam lingkungan perairan dan keberadaannya secara alami sulit dihilangkan. Logam berat $\mathrm{Fe}, \mathrm{Mn}, \mathrm{Zn}$ dan Cumerupakan logam penting bagi organisme yang berfungsi untuk membantu proses fisiologis, terutama sebagai kofaktor enzim atau untuk pembentukan organ. Namun, apabila dalam konsentrasi yang berlebih, dapat menimbulkan efek toksik, sehingga harus tetap diwaspadai, karena apabila diakumulasi dalam jumlah besar tetap dapat membahayakan.

Berkaitan dengan hal itu, salah satu aspek penting dalam upaya pengendalian lingkungan adalah mengurangi konsentrasi logam-logam berat yang ada dalam lindi.Menurut Effendi, $\mathrm{H}(2003)$, konsentrasi logam $\mathrm{Fe}, \mathrm{Mn}$, $\mathrm{Zn}$ dan $\mathrm{Cu}$ pada perairan alami, yaitu Fe sebesar 0,05-0,2 mg/liter; Mn sebesar 0,2 mg/liter; Zn sebesar <0,05 $\mathrm{mg} / \mathrm{liter}$ dan $\mathrm{Cu}$ sebesar <0,002 $\mathrm{mg} /$ liter.Berdasarkan hal tersebut, penelitian penyisihan kandungan logam Fe pada lindi ini dilakukan. Penelitian ini,menggunakan Instalasi Pengolahan Lindi Compact (IPLC) yang merupakan pengembangan dari Instalasi Pengolahan Lumpur Tinja Compact (IPLTC) yang didesain dengan skala pilot plant, dengan volume lebih kecil dari pengolahan yang ada di TPA Sarimukti, yaitu $1,063 \mathrm{~m}^{3}$.Reaktor ini dilengkapi dengan serangkaian unit pengolahan, yaitu grit chamber, grease trap, primary clarifier, anaerobic biological filter, anoxic chamber, moving bed biological reactor (MBBR) dan secondary clarifier. Penelitian ini memberikan unittambahan berupaactivated sand filter, yang berfungsi untuk mengurangi kandungan logam berat.Pada penelitian ini, pengukuran parameter pendukung, yaitu $\mathrm{pH}$, suhu, DO, kekeruhan dan TSS; digunakan sebagai penunjang dalam menganalisis parameter utama, yaitu Fe. Hasil akhir dari penelitian ini diharapkan akan diketahui efisiensi dan efektifitas dari IPLC. 


\section{METODOLOGI}

Tahapan pada penelitian ini adalah studi pustaka, persiapan penelitian, penelitian pendahuluan, pengukuran karakteristik awal, pengoperasian IPLC, analisispembahasan dan kesimpulan.

Studi pustakamerupakancara yang dilakukan untuk menghimpun informasi yang relevan dengan masalah yang sedang diteliti. Studi pustaka dapat diperoleh dari buku-buku ilmiah, laporan penelitian, karangan-karangan ilmiah, tesis dan disertasi,peraturan-peraturan,buku, ensiklopedia, dan sumber-sumber tertulis baik tercetakmaupunelektronik. Studi pustaka merupakan hal penting untuk dapat menunjang penelitian.Untuk persiapan pada penelitian ini terdapat 3 tahapan, yaitu: persiapan alat danbahan, seeding sertaaklimatisasi.

a. Persiapan alat dan bahan

Alat yang dipersiapkan dalam penelitian ini merupakan alat yang mendukung dalam proses penyisihan logam berat, yaituaerator, pompa dan valve pengatur debit. Skema rangkaian proses penyisihan logam berat menggunakan IPLC dapat dilihat pada Gambar 1.

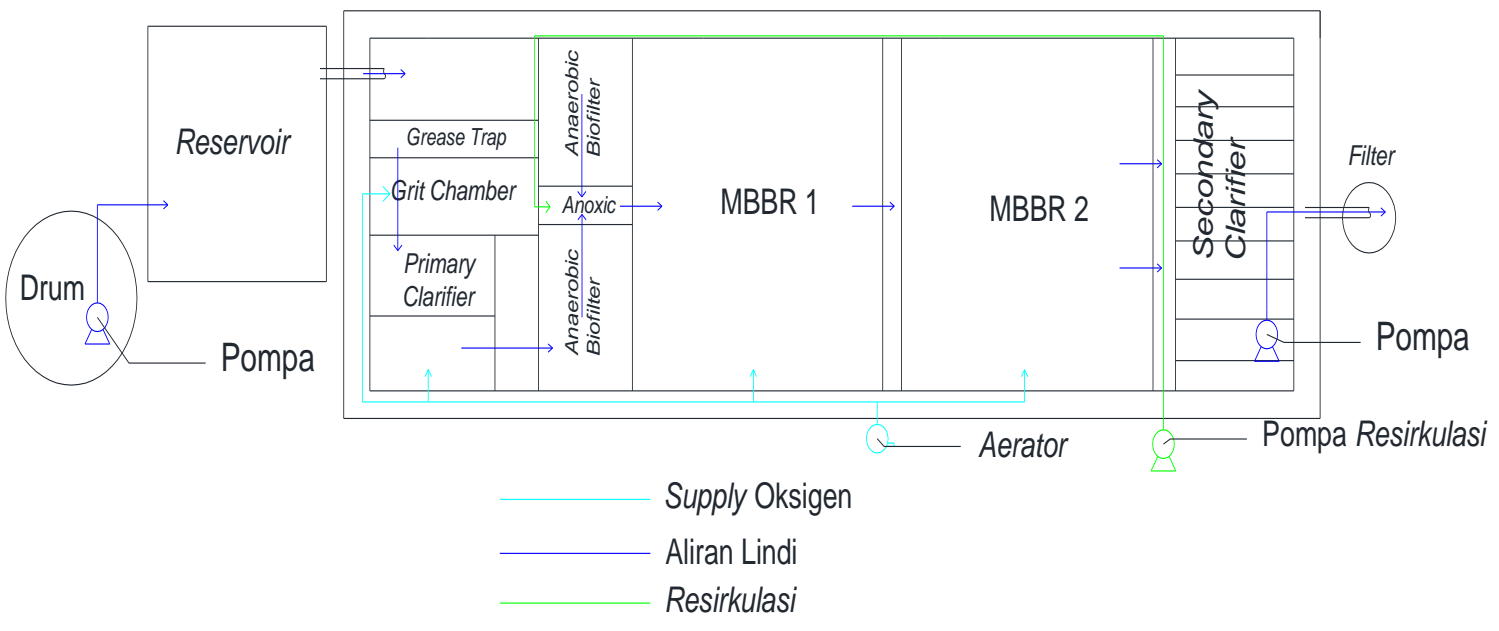

Gambar 1. Rangkaian Alat IPLC

Pada penelitian ini, aerator berfungsi sebagai alat yang menyuplai udara pada unit grit chamber, primary clarifier, MBBR 1 dan MBBR 2. Suplai udara ini diutamakan pada unit MBBR 1 dan 2. Hal ini dikarenakan pada unit tersebut terdapat mikroorganisme lekat yang dikondisikan secara aerob. Persiapan bahan yang dibutuhkan dalam penelitian ini didasarkan pada Standar Nasional Indonesia(SNI) dan StandardMethode Water and Wastewater (SMWW), seperti yang disajikan pada Tabel1.

b. Seeding

Bakteri yang digunakan pada tahap seedingini merupakan jenis bakteri fakultatif. Menurut Rifaldi (2015) dalam (Rochmah, Lela 2017), sebelum digunakan, mikroorganisme ini dilarutkan kedalam 10 liter lindi dalam ember yang memiliki volume 60 liter dan didiamkan selama 24 jam. Pada proses seeding, diberikan penambahan substrat sebanyak 50 liter dan media kaldness sebanyak 13 liter atau setara dengan $2 \mathrm{~kg}$. 
Tabel 1. Metode Pengukuran yang Digunakan

\begin{tabular}{lll}
\hline \multicolumn{1}{c}{ Parameter } & \multicolumn{1}{c}{ Prinsip Pengukuran } & \multicolumn{1}{c}{$\begin{array}{c}\text { Metode } \\
\text { Pengukuran }\end{array}$} \\
\hline Logam (Fe, Mn, Zn dan Cu) & $\begin{array}{l}\text { Atomic absorption spectrometer and associated } \\
\text { equipment }\end{array}$ & SMWW 3111 C \\
pH & Electroda Potensiometri & SNI 06-6989.11-2004 \\
Suhu & Idem & Idem \\
DO & Elektrometri & SNI 06-6989.14-2004 \\
TSS & Gravimetri & SNI 06-6989.3-2004 \\
Kekeruhan & Turbidimetri & SNI06-6989.25-2005 \\
\hline Sumber : SMWW dan SNI & & \\
C. Aklimatisasi & & \\
\end{tabular}

Tahap aklimatisasi adalah tahap pengkondisian mikroorganisme agar dapat hidup dan melakukan adaptasi. Pada tahap ini, diharapkan mikroorganisme tersebut dapat tumbuh dan berkembang biak dengan baik dengan pemberian nutrient berupa glukosa $\left(\mathrm{C}_{6} \mathrm{H}_{12} \mathrm{O}_{6}\right)$ kepada bakteri sampai kadar COD menjadi tunak (fluktuasi <10\%) (Dworkin dkk., 2006).Parameter yang diamati adalah mixed liqour volatile suspended solids (MLVSS), sebagai parameter acuan yang menunjukkan konsentrasi mikroorganisme yang tumbuh; dan COD yang menunjukkan ketersediaan kandungan mikroorganisme. Pada tahap ini,penambahan media kaldness dan substratdilakukan secara bertahap. Penambahan media kaldness dan substrat pada proses aklimatisasi dapat dilihat pada Tabel $\mathbf{2}$.

Tabel 2. Penambahan Media Kaldnesspada Proses Aklimatisasi dan Substrat

\begin{tabular}{ccccc}
\hline Penambahan & \multicolumn{4}{c}{ Proses } \\
\cline { 2 - 4 } & $\begin{array}{c}\text { Aklimatisasi } \\
\text { Tahap 1 } \\
\text { (Liter) }\end{array}$ & $\begin{array}{c}\text { Aklimatisasi } \\
\text { Tahap 2 } \\
\text { (Liter) }\end{array}$ & $\begin{array}{c}\text { Aklimatisasi } \\
\text { Tahap 3 } \\
\text { (Liter) }\end{array}$ & $\begin{array}{c}\text { Jumlah Kaldness } \\
\text { (Liter) }\end{array}$ \\
\hline Kaldnes & & 25 & 44 & 69 \\
MBBR 1 & - & 25 & 37 & 62 \\
MBBR 2 & - & $\mathbf{1 / 3}$ & $\mathbf{1 / 2}$ & $\begin{array}{c}\text { Jumlah Substrat } \\
\text { (Liter) }\end{array}$ \\
Substrat & $\mathbf{1 / 6}$ & 50 & 75 & 150 \\
MBBR 1 & 25 & 50 & 75 & 150 \\
MBBR 2 & 25 & & &
\end{tabular}

\subsection{Penelitian Pendahuluan}

Penelitian pendahuluan yang dilakukan adalah tracer test, yang bertujuan untuk mengetahui waktu detensi aktual dan distribusi aliran dalam reaktor IPLC. Bahan baku yang digunakan, yaitu $\mathrm{NaCl}$ yang bersifat inert sebanyak 33,67 gr dengan konsentrasi $50 \mathrm{mg} / \mathrm{l}$,sehingga dapat dilakukan pengukuran Daya Hantar Listrik (DHL) (Environmental Protection Agency, 2001 dalam Rochmah, Lela 2017). Metode pengukuran DHL dilakukan dengan metode konduktivimetri yang didasarkan padaSNI 06-6989.1-2004. Proses tracer test dapat tercapai jika konsentrasi $\mathrm{NaCl}$ yang dibubuhkan di inlet bak penampung IPLC sama dengan outlet,yaitu pada unit activated sand filtersebesar $50 \mathrm{mg} / \mathrm{L}($ Rochmah, Lela 2017). Tracer testdilakukan dengan metode step dose dan pengambilan sampel secara grab sampling (Rochmah, Lela 2017). Dalam menentukan waktu detensi terdapat perhitungan-perhitungan 
yang dilakukan, yaitu Mean Residence Time(MRT), variansi dan koefisien variansi, Retention Time Distribution(RTD).Selain itu, untuk menentukan pola aliran dilakukan perhitungan,seperti:moriil dispersion index, volumetric efficiency (\%) dan dispersion number.

\subsection{Pengoperasian IPLC}

IPLC dioperasikan dengan debit 0,01 liter/detik (Rochmah, Lela 2017). Debit inlet dan outlet diatur dengan debit yang sama agar tidak terjadi peluapan. Pengaturan debit ini dilakukan secara manual dengan menampung sebanyak $100 \mathrm{ml}$ dalam waktu 10 detik. IPLCdioperasikan dengan waktu detensi yang diperoleh dari tracer test, yaitu selama 31,33 jam. Perhitungan efisiensi logam pada IPLC dilakukan dalam 2 kali running dengan menggunakan lindi dari TPA Sarimukti yang telah berusia $>10$ tahun. Running dilakukan ketika proses seeding dan aklimatisasi selesai. Menurut Rochmah, Lela (2017), pengambilan sampel dilakukan bergantung pada waktu detensi dari setiap unit di IPLC. Waktu detensi tiap unit didapatkan dari perbandingan volume air dalam unit pengolahan dengan total volume air dalam reaktor IPLC yang dikalikan waktu detensi hasil dari tracer test. Hasil waktu detensi yang didapatkan dari tracer test dapat dilihat pada Tabel 3.

Tabel 3. Waktu Detensi Unit IPLC

\begin{tabular}{|c|c|c|c|c|c|c|c|c|c|}
\hline \multirow{2}{*}{$\begin{array}{c}\text { No. } \\
1\end{array}$} & \multirow{3}{*}{\begin{tabular}{l}
\multicolumn{1}{c}{ Unit } \\
pengolahan
\end{tabular}} & \multicolumn{3}{|c|}{$\begin{array}{c}\text { Dimensi bagian } \\
\text { dalam }(\mathrm{m})\end{array}$} & \multirow{2}{*}{$\begin{array}{r}\begin{array}{r}\text { Volume } \\
\text { teoritis } \\
\left(\mathbf{m}^{3}\right)\end{array} \\
0,098\end{array}$} & \multirow{2}{*}{$\begin{array}{l}\text { Volume } \\
\text { air di } \\
\text { IPLC } \\
\left(\mathbf{m}^{3}\right)\end{array}$} & \multirow{2}{*}{$\begin{array}{c}\begin{array}{c}\text { Volume } \\
\text { air } \\
\text { perunit } \\
\left(\mathbf{m}^{3}\right)\end{array} \\
0,097\end{array}$} & \multirow{2}{*}{$\begin{array}{c}\text { Td } \\
\text { IPLC } \\
\text { dari } \\
\text { tracer } \\
\text { test } \\
\text { (Jam) }\end{array}$} & \multirow{2}{*}{$\begin{array}{r}\begin{array}{c}\text { Td } \\
\text { perunit } \\
\text { (Jam) }\end{array} \\
2,860\end{array}$} \\
\hline & & 0,355 & 0,345 & 0,800 & & & & & \\
\hline 2 & & 0,290 & 0,335 & 0,800 & 0,078 & & 0,077 & & 2,270 \\
\hline 3 & Gutter 1 & 0,055 & 0,345 & 0,800 & 0,015 & & 0,150 & & 4,423 \\
\hline 4 & $\begin{array}{l}\text { Anaerobic } \\
\text { biofilter } 1\end{array}$ & 0,200 & 0,335 & 0,800 & 0,054 & & 0,053 & & 1,563 \\
\hline 5 & $\begin{array}{l}\text { Anaerobic } \\
\text { biofilter } 2\end{array}$ & 0,200 & 0,275 & 0,800 & 0,044 & & 0,043 & & 1,268 \\
\hline 6 & $\begin{array}{l}\text { Anoxic } \\
\text { chamber }\end{array}$ & 0,200 & 0,065 & 0,800 & 0,010 & 1,063 & 0,010 & 31,33 & 0,295 \\
\hline 7 & $M B B R 1$ & 0,485 & 0,695 & 0,800 & 0,270 & & 0,266 & & 7,843 \\
\hline 8 & Gutter 2 & 0,060 & 0,695 & 0,800 & 0,033 & & 0,033 & & 0,973 \\
\hline 9 & MBBR 2 & 0,440 & 0,695 & 0,800 & 0,245 & & 0,241 & & 7,106 \\
\hline 10 & Gutter 3 & 0,046 & 0,695 & 0,800 & 0,026 & & 0,035 & & 1,032 \\
\hline 11 & $\begin{array}{l}\text { Secondary } \\
\text { clarifier }\end{array}$ & $0 ., 310$ & 0,695 & 0,800 & 0,172 & & 0,170 & & 5,012 \\
\hline 12 & $\begin{array}{l}\text { Activated } \\
\text { sand filter }\end{array}$ & 0, & & 1 & 0,018 & & 0,000 & & 0,750 \\
\hline & Total & & & & 1,063 & & & & \\
\hline
\end{tabular}

Analisis yang akan dilakukan,yaitu analisis terhadap karakteritik sampel lindi TPA Sarimukti, efisiensi dan efektifitaspenyisihan logam pada IPLC. 


\section{Hasil dan Pembahasan}

\subsection{Karakteristik Lindi TPA Sarimukti}

Sebelum melakukan proses pengolahan, maka perlu diketahui karakteristik sampel lindi TPA Sarimukti. Data yang diperoleh akan dibandingkan dengan dua baku mutu, yaitu untuk $\mathrm{pH}$, TSS, COD dan $\mathrm{BOD}_{5}$ dibandingkan dengan Permen LH No. 59 Tahun 2016; sedangkan untuk parameter Fe dibandingkan dengan baku mutu Permen LHNo. 5 Tahun 2014. Hal ini dikarenakan, pada peraturan NSPM PU (Norma Standar Pedoman Manual, Pekerjaan Umum) tahun 2007 dan P.59 tahun 2016, tidak terdapat baku mutu untuk parameter logam berat Fe untuk lindi. Selain itu, penggunaan peraturan ini didasarkan atas penggunaan peraturan yang dipakai oleh pihak TPA Sarimukti sendiri. Perbandingan baku mutu yang digunakan adalah golongan II, karena memiliki karakteristik BOD sebesar 1.593,29 mg/l dan COD sebesar 6.400 mg/l (Rasyahid, Soca 2017). Hasil uji karakteristik dapat dilihat pada Tabel 4.

Tabel 4. Perbandingan Baku Mutu dengan Karakteristik Awal Lindi TPA Sarimukti

\begin{tabular}{|c|c|c|c|c|c|}
\hline \multirow[b]{2}{*}{ Parameter } & \multirow[b]{2}{*}{ Satuan } & \multirow[b]{2}{*}{ Konsentrasi } & \multicolumn{2}{|c|}{ Baku Mutu } & \multirow[b]{2}{*}{ Keterangan } \\
\hline & & & $\begin{array}{l}\text { PerMen LH No. } \\
59 \text { Tahun } 2016 \\
(*)\end{array}$ & $\begin{array}{c}\text { Permen LH No. } \\
5 \text { Tahun } 2014 \\
(* *)\end{array}$ & \\
\hline $\mathrm{pH}$ & & $8,3-8,65$ & $6-9$ & - & Memenuhi \\
\hline Suhu & ${ }^{\circ} \mathrm{C}$ & $25,6-26,7$ & - & 40 & Memenuhi \\
\hline $\mathrm{Fe}$ & $\mathrm{mg} / \mathrm{l}$ & $6,58-9,784$ & - & 10 & Memenuhi \\
\hline TSS & $\mathrm{mg} / \mathrm{l}$ & $470-556$ & 100 & - & $\begin{array}{c}\text { Tidak } \\
\text { Memenuhi }\end{array}$ \\
\hline COD & $\mathrm{mg} / \mathrm{l}$ & $4.800-6.400$ & 300 & - & $\begin{array}{c}\text { Tidak } \\
\text { Memenuhi }\end{array}$ \\
\hline $\mathrm{BOD}_{5}$ & $\mathrm{mg} / \mathrm{l}$ & $\begin{array}{c}1.071,55- \\
1.593,29\end{array}$ & 150 & - & $\begin{array}{c}\text { Tidak } \\
\text { Memenuhi }\end{array}$ \\
\hline
\end{tabular}

*Tentang Baku Mutu Lindi Bagi Usaha dan/atau Kegiatan Tempat Pemrosesan Akhir Sampah ** Tentang Air Limbah

Berdasarkan Tabel 4, parameter yang memenuhi baku mutu, yaitu $\mathrm{pH}$, suhu, $\mathrm{Zn}, \mathrm{Cu}, \mathrm{Fe}$ dan Mn; sedangkan yang tidak memenuhi baku mutu, yaitu TSS, COD dan $\mathrm{BOD}_{5}$. Konsentrasi TSS mencapai 470-556 mg/l tidak memenuhi baku mutu Permen LH No. 59 tahun 2016, yang ditetapkan sebesar $100 \mathrm{mg} / \mathrm{l}$. Konsentrasi COD mencapai 4.800-6.400 mg/l, sehingga tidak memenuhi baku mutu yang ditetapkan, yaitu $300 \mathrm{mg} / \mathrm{l}$. Untuk BOD ${ }_{5}$ didapatkan konsentrasi mencapai 1.071,55-1.593,29 mg/l, oleh karena itu tidak memenuhi baku mutu yang ditetapkan, yaitu sebesar $150 \mathrm{mg} / \mathrm{l}$.Karakteristik awal yang didapatkan pada Tabel 4,akan dibandingkan dengan pernyataaan Renoui et al, pada Tabel 5, mengenai tipikal kualitas lindi pada variasi umur landfill.

Tabel 5. Klasifikasi Karakter Lindi Menurut Umur Landfill

\begin{tabular}{lccc}
\hline \multicolumn{1}{c}{ Parameter } & Muda Umur $<\mathbf{5}$ & Sedang Umur (5-10) & Tua Umur $(\mathbf{1 0 )}$ \\
\hline $\mathrm{pH}$ & 6,5 & $6,5-7,5$ & $>7,5$ \\
$\mathrm{COD}\left(\mathrm{mgL}^{-1}\right)$ & $>10.000$ & $4.000-10.000$ & $<4.000$ \\
$\mathrm{BOD}_{5} / \mathrm{COD}$ & $>0,3$ & $0,1-0,3$ & $<0,1$ \\
Logam Berat & Rendah-Sedang & & Rendah \\
Biodegradable & Tinggi & Sedang & Rendah \\
\hline
\end{tabular}

Sumber : Renoui et al, 2007

[Reka Lingkungan] - 83 
Nilai pH pada TPA Sarimukti berkisar antara 8,3-8,65. Jika dibandingkan dengan Peraturan MenteriLingkungan Hidup Permen LH No. 59 Tahun 2016, maka pH telah memenuhi baku mutu (Tabel 4). Kondisi pH tersebut sesuai dengan pernyataan Renouiet al, (2007), bahwa nilai $\mathrm{pH}$ lindi TPA yang berumur tua $>10$ tahun, yaitu lebih dari 7,5(Tabel 5).pH merupakan salah satu parameter yang penting dalam kelarutan logam. Nilai $\mathrm{pH}$ yang tinggi menunjukkan bahwa lindi ini memiliki kondisi basa, sehingga kenaikan $\mathrm{pH}$ ini dapat menurunkan kelarutan logam dalam air (Effendi, 2003).

Nilai suhu pada TPA Sarimukti memiliki nilai sebesar $25,6-26,7^{\circ} \mathrm{C}$.Suhu merupakan parameter yang dapat mempengaruhi kelarutan logam berat dalam perairan. Nilai suhu yang lebih rendah akan meningkatkan adsorpsi logam partikulat untuk mengendap, sedangkan saat suhu air naik, senyawa logam berat akan terlarutkan dalam air karena penurunan laju adsorpsi ke dalam partikulat (Pallar,H., 1994).

Pengukuran konsentrasi logam berat yang didapatkan untuk Fe sebesar 6,580-9,784 mg/l. Hal tersebut sesuai dengan pernyataan Renouiet al(2007) bahwa nilai logam berat lindi pada TPA yang berumur tua itu rendah (Tabel 5). Jika dilihat dari keempat konsentrasi karakteristik awal, logam Fe memiliki nilai yang mendekati batas baku mutu yang diperbolehkan, sehingga pembahasan penyisihan logam oleh IPLC pada jurnal ini hanya difokuskan pada logam Fe.

Nilai Total Suspended Solid (TSS)pada TPA Sarimukti berkisar antara470-556mg/l. Nilai TSS ini berkolerasi positif dengan kekeruhan.Jika dibandingkan dengan Permen LH No. 59 Tahun 2016, maka nilai TSS tersebut tidak memenuhi baku mutu (Tabel 4). Untuk nilai kekeruhan didapatkan sebesar 52,2-58,1 NTU. Menurut Davis dan Cornwell (1991) dalam Bariguna, Dipo(2008), kekeruhan menggambarkan adanya materi organik dan anorganik baik tersuspensi maupun terlarut dalam perairan.

Konsentrasi Dissolved Oxygen (DO) pada TPA Sarimukti memiliki nilai berkisar antara 5,57$5,95 \mathrm{mg} / \mathrm{l}$. Rendahnya kandungan DOpada air berpengaruh buruk terhadap kehidupan akuatik didalamnya. Minimnya kandungan oksigen terlarut mengakibatkan munculnya kondisi anaerobik dengan bau busuk dan permasalahan estetika. Ketersediaan oksigen juga bergantung pada suhu, karena kelarutan oksigen meningkat dengan berkurangnya suhu (Kadlec, R.H., 2009).

Pengukuran konsentrasi COD bertujuan untuk melihat kandungan organik yang sukar untuk terdegradasi. Konsentrasi COD pada TPA Sarimukti ini berkisar antara 4.800-6.400 mg/l. Pada penelitian ini juga dilakukan pengukuran BOD yang bertujuan untuk mengetahui organik yang mudah terbiodegradasi. Konsentrasi BOD $_{5}$ pada TPA Sarimukti ini berkisar antara $1.071,55-1.593,29 \mathrm{mg} / \mathrm{l}$. Rasio $\mathrm{BOD}_{5} / \mathrm{COD}$ yang diperoleh adalah 0,25 , dimana nilai tersebut jika dibandingkan dengan syarat untuk pengolahan secara biologi, yaitu $>0,5$, maka pengolahan biologi yang dilakukan dapat menjadi kurang efektif.Jika dibandingkan dengan Permen LH No. 59 Tahun 2016, maka nilai BOD dan COD tidak memenuhi baku mutu(Tabel 4).

\subsection{Efisiensi Penyisihan Logam Berat}

\section{a. Penyisihan Fe}

Penelitian ini difokuskan untuk menyisihkan parameter $\mathrm{Fe}$, karena konsentrasi pada karakteristik awal lindi di TPA Sarimukti telah mendekati baku mutu Permen LH No. 5 Tahun 
2014, yaitu 9,784 mg/l.Keberadaan besi dalam air dapat berupa $\mathrm{Fe}^{2+}$ yang merupakan besi terlarut dalam airdan $\mathrm{Fe}^{3+}$ besi yang terendapkan atau teroksidasi akibat adanya proses aerasi. Pada umumnya oksigen dalam air akan digunakan untuk mengoksidasi besi yang terlarut dalam air menjadi bentuk besi yang dapat mengendap. Adapun prosesnya adalah besi dalam bentuk ferro dioksidasi terlebih dahulu menjadi bentuk ferri, lalu terjadi pengendapan dengan membentuk ferri hidroksida; reaksi ini mudah terjadi pada kondisi $\mathrm{pH}$ 7 (Fair \& Geyer,J C. 1966).

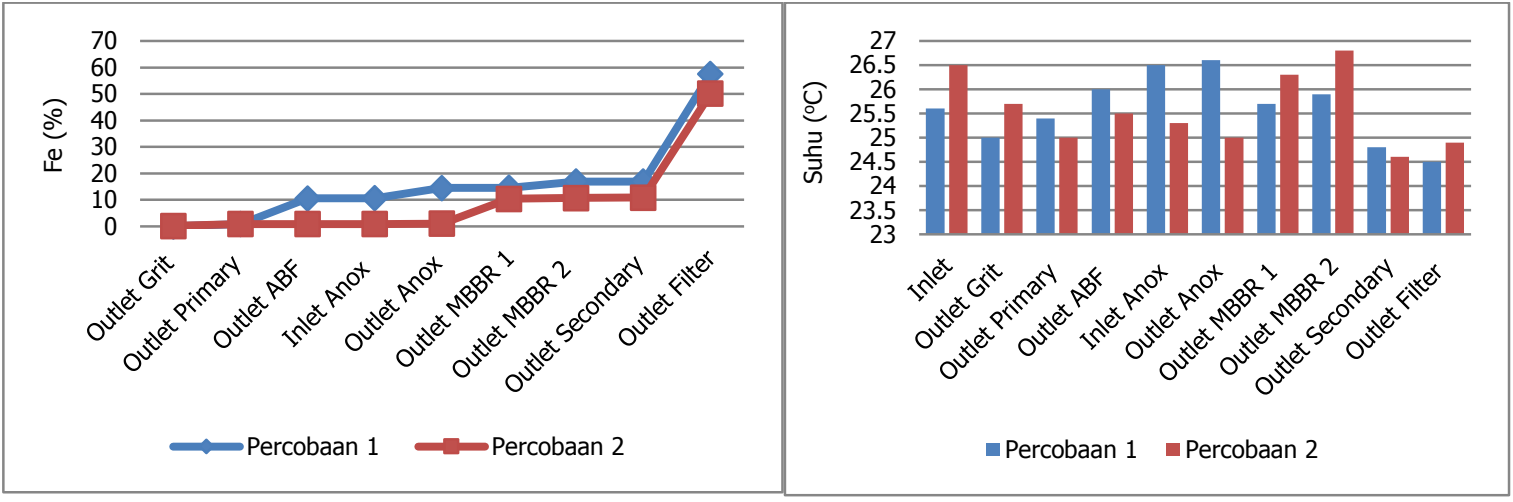

(a) (b)

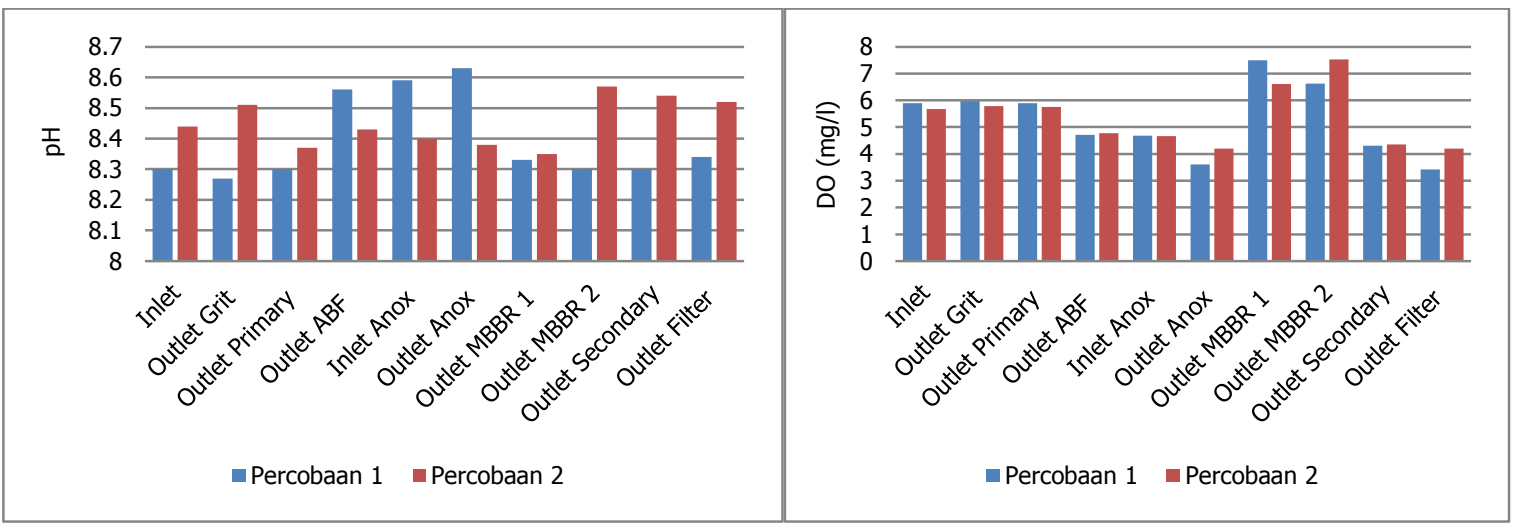

(c)

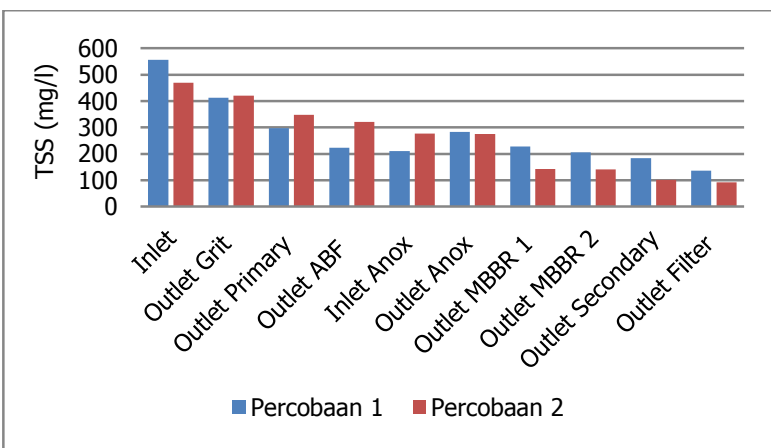

(e) (d)

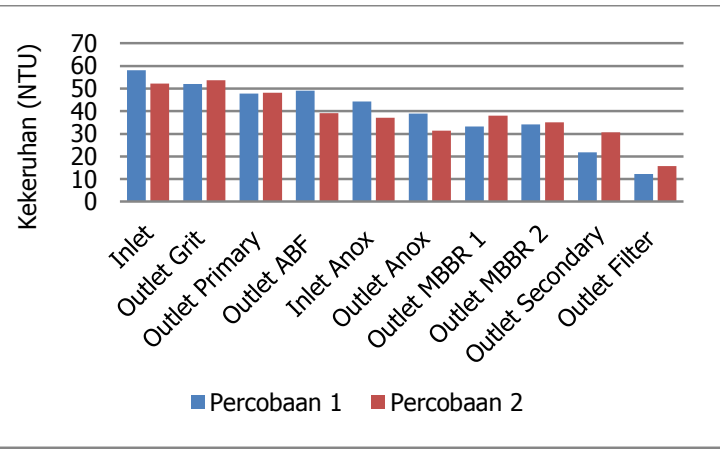

(f)

Gambar 2. Grafik (a) Efisiensi Penyisihan Logam Fe Perunit, (b)Kondisi Suhu Saat Pengolahan,(c) Kondisi pH Saat Pengolahan, (d) Konsentrasi DO Pada Saat Pengolahan, (e) Konsentrasi TSS Pada Saat Pengolahan dan (f) Nilai Kekeruhan Pada Saat Pengolahan (Sumber : Hasil Perhitungan, 2017) 
Pada percobaan pertama Gambar 2. (a), didapatkan nilai efisiensi sebesar 57,62\%. Nilai efisiensi penyisihan ini, dari inlet ke tiap unit mengalami kenaikan, terutama pada outlet filter. Jika dibandingkan dengan parameter suhu yang didapatkan, yaitu $24,5-26,6^{\circ} \mathrm{C}$,kondisi suhu yang diperoleh ini dipengaruhi oleh waktu pengambilan tiap sampel.Pada unit outlet filter didapatkan suhu paling rendah dibandingkan dengan unit lain, yaitu $24,5^{\circ} \mathrm{C}$ atau berada dibawah suhu ruang, sehingga proses adsorpsi logam pada media pasir dapat mudah terjadi. Menurut Boyd, 1991 dalam Tchobanoglous et al (2004), suhu air yang lebih dingin akan meningkatkan adsorpsi logam partikulat untuk mengendap.Menurut Muchtadi D. (1989), suhu optimum untuk mikroorganisme yang hidup pada suhu $25-37^{\circ} \mathrm{C}$ adalah golongan Mesophilic.

pH yang didapatkan basa berkisar 8,27-8,63. Hal ini memberikan keuntungan karenamenurut Boyd(1991) dalam Tchobanoglous et al (2004), kondisi ini akan menurunkan kelarutan logam dalam air; karena kenaikan $\mathrm{pH}$ mengubah kestabilan dari bentuk karbonat menjadi hidroksida, yang membentuk ikatan dengan pada badan air, sehingga akan membentuk lumpur. Pada percobaan pertama didapatkan nilai DO, yaitu berkisar 3,42-7,50 $\mathrm{mg} / \mathrm{l}$. Nilai terendah berada pada unit outlet filter, yaitu $3,42 \mathrm{mg} / \mathrm{l}$, sedangkan tertinggi terjadi pada unit MBBR 1 dan 2, disusul oleh unit grit chamber dan primary clarifier. Pada unit MBBR 1 dan 2, konsentrasi DO yang tinggi yaitu, 7,50-6,63 mg/l diperuntukkan bagi pertumbuhan mikroorganisme untuk mendegradasi bahan organik dan logam. Pada unit grit chamber dan primary clarifier didapatkan DO sebesar 5,97-5,89 mg/l. Hal ini didapatkan karena pada kedua unit diberikan suplai udara untuk mempermudah kecepatan pengendapan pasir, TSS dan memberikan dorongan agar terjadi aliran down flow. Berdasarkan Gambar 2.e, memperlihatkan konsentrasi TSS mengalami fluktuasi. Unit yang efisien dalam menurunkan TSS terjadi pada outlet filter. Pada percobaan pertama ini terjadi penurunan TSS dari unit grit chamber hingga inlet anoxic, lalu terjadi peningkatan pada outlet anoxic, namun terjadi penurunan kembali hingga outlet filter. Nilai TSS ini berbanding lurus dengan kekeruhan. Penurunan TSS ini mengindikasikanterjadi penurunan konsentrasi oleh proses pengendapan, baik zat organik ataupun logam-logam.Akan tetapi, nilai TSS yang didapatkan ini belum memenuhi baku mutu Permen LH No.59 tahun 2016.

Pada percobaan kedua (Gambar 2.a)didapatkan kenaikan efisiensiyang hampir sama dengan percobaan pertama; namun penyisihan meningkat dari mulai outlet anoxic ke outlet filter, dengan nilai efisiensi terbesar, yaitu pada outlet filter sebesar 50,13\%. Suhu pada unit outlet filterdiperoleh sebesar $24,9^{\circ} \mathrm{C}$. Pada umumnya Fe dapat didegradasi oleh bakteri Thiobacillus ferrooxidans, namun bakteri tersebut hanya dapat hidup pada suhu $45-50^{\circ} \mathrm{C}$ dan berada dalam $\mathrm{pH}$ 1,5-2,5. DO didapatkan sebesar 4,2 mg/l untuk unit outlet filter. Pada IPLC ini terdapat unit yang dioperasikan secara anaerob, yaitu anaerob biological filter dan anoxic. Akan tetapi nilai DO yang didapatkan tidak sesuai dengan yang diharapkan karena menurut Gray N. F (2004), pada unit anaerob dan anoksicseharusnya memiliki konsentrasi DO \pm 1 $\mathrm{mg} / \mathrm{l}$. TSS menurun secara signifikan.Konsentrasi TSS terendah didapatkan pada unit outlet filter, yaitu 92,5 mg/l. Jika dibandingkan dengan Permen LH 59 tahun 2016, maka nilai ini telah memenuhi baku mutu yang ditetapkan, yaitu 100 mg/l untuk golongan II. Karena nilai TSS ini berbanding lurus dengan kekeruhan maka didapatkan nilai kekeruhan, pada outlet filter sebesar 15,71 NTU (Gambar 2.f).

Berdasarkan data yang didapatkan pada Gambar 2. (a), dapat disimpulkan bahwa unityangpaling efisien, yaituoutlet filter, dengan nilai rata-rata sebesar 53,87\%. Pada unitfilter, konsentrasi Fe menurun, karena unit ini dirancangdengan menggunakan activated sand yang mengandung pasir silika dan $\mathrm{KMnO}_{4}$. Reaksi yang terjadi adalah sebagai berikut (Novita, Dian2005): 
$3 \mathrm{Fe}^{2+}+\mathrm{KMnO}_{4}+7 \mathrm{H}_{2} \mathrm{O} \rightarrow 3 \mathrm{Fe}(\mathrm{OH})_{3}+\mathrm{MnO}_{2}+\mathrm{K}^{+}+5 \mathrm{H}^{+}$

Pada unit filter initerdapat kontak antara oksigen dan limbah dengan cara memberikan jarak jatuh lindi sebelum ke media pasir, yaitu setinggi $20 \mathrm{~cm}$, sehinggadiharapkan terjadi proses aerasi yang akan membantu proses oksidasi besi (Novita, Dian 2005). DO yang diperoleh pada saat proses filtrasi didapatkan sebesar 4,2 $\mathrm{mg} / \mathrm{l}$ (Gambar d). Selain itu, dalam penelitian ini saringan activated sand filter dioperasikan dalam kondisi aliran tak jenuh (unsaturated), sehingga dalam pengoperasiannya, tidak terdapat komponen supernatan atau genangan air di atas media pasir. Pada kondisi tak jenuh, hanya sebagian dari pori yang terisi air, sedangkan selebihnya berisi udara. Kondisi ini memberikan keuntungan berupa peningkatan daya kontak limbah dengan udara, saat air melewati pori-pori pasir. Pada proses aerasi inilah proses oksidasi terjadi. Menurut Rich, Linvil G(1963), pH yang baik untuk proses oksidasi adalah 7,8 atau netral dan banyak mengandung oksigen, sedangkan nilai $\mathrm{pH}$ yang didapatkan pada unit outlet filter ini sebesar 8,54, dapat dilihat pada Gambar 2. (d). Hal ini dikarenakan umur TPA yang $>10$ tahun sehingga nilai $\mathrm{pH}$ lindi lebih dari 7,5 (Renoui et al, 2007)(Tabel 4). Penurunan kadar besi dalam air pada hakikatnya mengubah dari bentuk yang larut dalam air menjadi mengendap. Reaksi oksidasi Fe (II) dapat terjadi dalam fasa homogen dan heterogen sesuai dengan persamaan stoikiometri sebagai berikut (Novita, Dian2005):

$$
\mathrm{Fe}^{2+}+1 / 4 \mathrm{O}_{2}+2 \mathrm{OH}^{-}+1 / 2 \mathrm{H}_{2} \mathrm{O} \rightarrow \mathrm{Fe}(\mathrm{OH})_{3}
$$

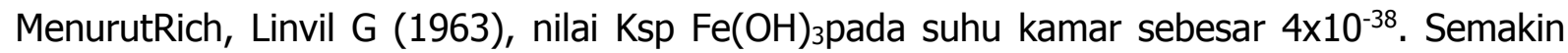
kecilnilai Ksp,akan semakin sukar larut dalam pelarutnya.Kelarutan logam Fe memiliki nilai paling rendah, jika dibandingkan dengan logam lainnya, seperti $\mathrm{Cu}$, Zn dan Mn. Nilai Ksp Fe dapat dilihat pada Tabel 6.

Tabel 6. Nilai Kelarutan Logam Fe

\begin{tabular}{|c|c|c|c|c|c|c|}
\hline \multirow[t]{2}{*}{ Parameter } & \multirow[t]{2}{*}{ Ksp } & \multirow[t]{2}{*}{$\begin{array}{c}\text { pH } \\
\text { Teori }\end{array}$} & \multirow[t]{2}{*}{$\begin{array}{c}\text { pH pada } \\
\text { Pengoperasian }\end{array}$} & $\begin{array}{r}\text { Efis } \\
\text { Peny } \\
(\%) \\
\text { Pengop } \\
\text { K }\end{array}$ & $\begin{array}{l}\text { Isi } \\
\text { han } \\
\text { Ida } \\
\text { asian }\end{array}$ & \multirow[t]{2}{*}{$\begin{array}{c}\text { Rata- } \\
\text { rata } \\
(\%)\end{array}$} \\
\hline & & & & 1 & 2 & \\
\hline Besi (Fe) & $\mathrm{Fe}(\mathrm{OH})_{3} \rightarrow 4 \times 10^{-38}$ & $7,8-8,5$ & 8,$34 ; 8,52$ & 57,62 & 50,13 & 53,87 \\
\hline
\end{tabular}

\subsection{Perbandingan Dengan Baku Mutu}

Berdasarkan data yang didapatkan,terjadi penurunan konsentrasi Fe dari karakteristik awal, yaitu 6,580-9,784 mg/l; dan setelah dilakukan pengolahan oleh IPLC didapatkan konsentrasi akhir Fe sebesar 2,789 mg/l pada percobaan pertama dan $4,879 \mathrm{mg} / \mathrm{l}$ pada percobaan kedua.

\section{KESIMPULAN}

Unit yang optimum dalam menyisihkan logamberatFe adalah unit outlet filter.Kondisi $\mathrm{pH}$ yang didapatkan berkisar antara 8,34-8,52; nilai DO berkisar antara 3,42-4,2 $\mathrm{mg} / \mathrm{l}$.Berdasarkan hasil penelitian IPLC mampu menyisihkan Fe sebesar53,87\% dari konsentrasi awal. 


\section{DAFTAR RUJUKAN}

Bariguna, Dipo. (2008). Studi Tingkat Kekeruhan Air Menggunakan Citra Radar Airsar. IPB, Bogor

Damanhuri, E. (2008). Diktat Teknik Pengelolaan Sampah. Penerbit ITB, Bandung

Darmono.(1995). Logam Dalam Sistem Biologi Mahluk Hidup. UI Press, Jakarta

Dworkin, M., FAlkow, S., Rosenberg, E., Schleifer, K-H.,Stackebrandt, E. (2006). The prokaryotes third. Symbiotic Association, Biotechnology, Applied Microbiology. Vol1.

Effendi, H. (2003). Telaah Kualitas Air bagi Pengolahan Sumber Daya dan Lingkungan Perairan. Penerbit Kanisius, Yogyakarta

Fair and Geyer, J C.(1966). Water and Wastewater Treatment, John Wiley and Sons Inc, New York.

Gray N. F. (2004). Biology of wastewater treatment (Vol. 4): World Scientific.

Kadlec, R. H. (2009). Comparison of Free Water and Horizontal Subsuface Treatment Wetlands. Ecological Enggineering, Vol. 35, p : 159-174

Muchtadi D. (1989). Evaluasi Nilai Gizi Pangan. Departemen Pendidikan dan Kebudayaan Direktorat Jenderal Pendidikan Tinggi Pusat Antar Universitas Pangan dan Gizi, Institut Pertanian Bogor, Bogor

Novita, Dian. (2005). Saringan Pasir Kering Aktif Ununiform sebagai Alternatif Penurunan Konsentrasi Besi dan Mangan dalam Air Tanah. Itenas, Bandung

Pallar, H., (1994). Pencemaran dan Toksikologi Logam Berat. Rineka Cipta, Jakarta.

Parsons. (2002). Impact of Landfill Closure Design on Long- Term Natural Attenuation of Chlorinated Hydrocarbons, Environmental Security Technology Certification Program, Arlington

Peraturan Menteri Lingkungan Hidup dan Kehutanan Republik Indonesia Nomor. 5 Tahun 2016 Tentang Baku Air Limbah

Peraturan Menteri Lingkungan Hidup dan Kehutanan Republik Indonesia Nomor. P.59/Menlhk/Setjen/ Kum.1/7/2016 Tentang Baku mutu Lindi Bagi Usaha dan/atau Kegiatan Tempat Pemrosesan Akhir Sampah

Pratama, Y., dan Soleh, A, Z. (2010). Identifikasi Faktor-Faktor Dominan yang Mempengaruhi Penilaian Masyarakat terhadap Keberlangsungan TPA Sarimukti di Kabupaten Bandung. Jurnal Ilmiah Unpad. Universitas Padjajaran, Bandung

Rasyahid, Soca.(2017). Efektifitas Instalasi Pengolahan Lindi (IPL) Compact DalamMenyisihkan Organik Dan Padatan Tersuspensi Dengan Sistem Aliran Kontinu. Itenas, Bandung

Renoui, et., al.(2007). " Landfill Leachete Treatment : Review and Opportunity" Journal of Hazardous Materials 150 (2008) 468-493.

Rich, Linvil G. (1963).Unit Processes of Sanitary Engineering, John Wiley and Sons Inc, New York

Rochmah,Lela. (2017). Efektifitas Instalasi Pengolahan Lumpur Tinja (IPLT) CompactDalam Menyisihkan Organik Dan Padatan Tersuspensi Dengan Sistem Aliran Kontinu. Itenas, Bandung

Standar Nasional Indonesia. (2004). Tata Cara Pengukuran DO Oleh Electrometri (Vol. SNI 06-6989.14-2004). Badan Standarisasi Nasional, Jakarta

Standar Nasional Indonesia. (2004). Tata Cara Pengukuran Kekeruhan Oleh Turbidimetri (Vol. SNI 06-6989.25-2004). Badan Standarisasi Nasional, Jakarta

Standar Nasional Indonesia. (2004). Tata Cara Pengukuran pH Oleh Electroda Potensiometri (Vol. SNI 06-6989.11-2004). Badan Standarisasi Nasional, Jakarta

Standar Nasional Indonesia. (2004). Tata Cara Pengukuran TSS Secara Gravimetri (Vol. SNI 06-6989.3-2004). Badan Standarisasi Nasional, Jakarta 
Standard Methods for Examination Water and Wastewater.(1995). American Public: Health.

Sugihhartati Dj Rachmawati, Chedly Tizaoui, Nidal Hilal. (2013). Removal of metals (copper, manganese, nickel and zinc) from waters by activated unsaturated sand filter (AUSF). Jurusan Teknik Lingkungan. Itenas, Bandung

Tchobanoglous, George and Theisen H, Vigil SA. (1993). Integrated Solid Waste Management: Engineering Principles and Management Issues. McGraw-Hill, Inc., N.Y

Tchobanoglous G., et al. (2004). Wastewater Engineering: Treatment and Resource Recovery, ; Metcalf \& Eddy I AECOM: McGraw-Hill Book Company: New York, NY, USA.

Vogel.(1995). Organic Chemistry, American Book Company,New York

Vogel. (1986). Buku Teks Analisis Secara Kualitatif Makro dan Semimikro. PT. Kalman Media Pustaka, Jakarta 